\title{
SME Profitability of Trade Credit during and after a Financial Crisis: Evidence from Korea
}

\author{
Ohsung KWON'1, Seung Hun HAN², Duk Hee LEE ${ }^{3}$ \\ Received: March 13, 2020 Revised: May 24, 2020 Accepted: June 10, 2020
}

\begin{abstract}
An economic downturn can occurred through unexpected events in various fields, such as the subprime mortgage crisis and the outbreak of Coronavirus Disease-2019 (COVID-19). Trade credit is important for small- and medium-sized enterprises (SMEs), especially during a monetary contraction, as it is the last option for firms that lack bank credit. This study aims to determine whether trade credit is profitable for the buyer and supplier firms during and after a financial crisis. We use panel data consisting of all trade credit transactions and financial statements of 5,751 Korean firms during the period 2008-2012. It shows that trade credit is more profitable for both buyers and suppliers in the post-crisis period than during the crisis. Moreover, trade payable is more effective for unconstrained buyers than for constrained buyers. Finally, a mixed strategy is superior to an aggressive or passive strategy of SMEs. The results suggest less profitability of trade credit during a period of contraction and greater sensitivity of the buyer SMEs, emphasizing the idiosyncratic liquidity strategy of each firm. This study can be helpful to develop a strategy of profitable trade credit for SMEs and to establish a policy of managing liquidity for the authority.
\end{abstract}

Keywords : Trade Credit, Financial Crisis, Credit Constraints, Financial Performance

JEL Classification Code: G32, L14, H81

\section{Introduction}

The financial crisis that started in 2008 disrupted the global financial system. Specifically, the ramifications of the bankruptcy of Lehman Brothers and Bear Stearns spread to other financial institutions (e.g., Fannie Mae, Freddie Mac, AIG, Citi, and Bank of America), and the spillover into the global financial markets threatened the world economy (Aloui, Ben Aissa, \& Nguyen, 2011; Longstaff, 2010; Samarakoon, 2011; Sohn \& Liu, 2015). During this turbulent

\footnotetext{
${ }^{1}$ First Author. Associate Research Fellow, Korea Institute for Industrial Economics \& Trade, Korea. Email: ohsung00@kiet.re.kr.

2Professor, School of Business and Technology Management, College of Business, KAIST, Korea. Email: synosia@kaist.ac.kr. ${ }^{3}$ Corresponding Author. Professor, School of Business and Technology Management, College of Business, KAIST, Korea. Email: dhlnexys@kaist.ac.kr.

(c) Copyright: The Author(s)

This is an Open Access article distributed under the terms of the Creative Commons Attribution Non-Commercial License (http://Creativecommons.org/licenses/by-nc/4.0/) which permits unrestricted noncommercial use, distribution, and reproduction in any medium, provided the unrestricted noncommercial
original work is properly cited.
}

period, the use of credit by firms was different from that in non-crisis periods. Extant literature also presents evidence that firms, especially small firms, rely on trade credit as a last option due to financial constraints, and this is known as the substitution hypothesis (Atanasova \& Wilson, 2004; Burkart \& Ellingsen, 2004; Huang, Shi, \& Zhang, 2011; Love, Preve, \& Sarria-Allende, 2007; Mateut, Bougheas, \& Mizen, 2006; Wilner, 2000). Therefore, as argued in the literature, trade credit plays an important role during financial crises. However, little information is available to substantiate how the substituted financing source of trade credit is effective and profitable during crises, specifically for overcoming the impact of an economic recession in the long term. Several existing studies that have investigated the positive impact of trade credit on firm performance did not consider financial crisis periods where trade credit acts a substitute for much of bank credit. Therefore, it is still unclear whether trade credit is more profitable and useful in a crisis than in the post-crisis period despite the importance of credit policy and firm strategy.

The existing literature explores why and how firms use trade credit in terms of both supply and demand. Broadly, buyer firms benefit when they use trade credit and their aggressive 
policy of trade credit benefits buyers. Similarly, although suppliers endure the insolvency risk of buyers, extending trade credit is profitable for them. Overall, previous studies dealt with the profitability of trade credit from the perspective of both buyers and suppliers, but did not consider trade credit as an approach to overcoming a monetary contraction. Moreover, during monetary contractions, firms will more likely rely on trade credit to offset the credit crunch. So far, studies have only investigated the determinants of trade credit during a crisis period. Consequently, this study attempts to fill the lacuna of whether trade credit can counteract the monetary shocks of a contractionary period and effectively improve the performance of firms in the long term using unique and transaction-based trade credit data in Korea.

Our main findings are as follows. First, the use of trade credit is more beneficial for both buyer and supplier SMEs in a post-crisis period than during the crisis. Second, unconstrained SMEs stand to benefit more than constrained SMEs while using trade payable during the post-crisis period, whereas the difference of profitability is negligible when using trade receivable. Third, a mixed strategy of using trade credit is a superior option compared with the continuous leveraging or deleveraging strategy of SMEs. Both buyers and suppliers expect that extending trade credit will positively affect their profitability in the postcrisis period, in other words, the importance of trade credit increases gradually after a crisis. This study contributes to the existing literature by establishing the financial performance of both buyers and suppliers during a crisis and post-crisis period by using transaction-level data. Moreover, in the macro view, it can propose an improved trade credit system for the balance between buyers and suppliers, the careful management of trade credit for regulating authorities, and the appropriate trade credit strategy for firms in the micro view.

The study is structured as follows. Section 2 introduces the literature review about trade credit. Section 3 describes data samples and variables. Section 4 presents the methodology and empirical strategy. Section 5 reports the results, and Section 6 concludes the study.

\section{Literature Review and Hypothesis Development}

\subsection{Monetary Contraction and Profitability}

As stated in Section 1, previous studies suggest that extending trade credit leads to higher profitability for buyer firms. Trade credit is used as a substitute by financiallyconstrained buyers (Huyghebaert, 2006). It enables suppliers to transact flexibly with their buyer and improve sales even during a period of monetary contraction (Wilson \& Summers, 2002). Trade credit can also reduce unnecessary costs due to various uncertainties on inter-firm contracts, i.e., trade credit permits suppliers to be more flexible in their transactions during a crisis period and facilitates price discrimination (Brennan, Maksimovic, \& Zechner, 1988; Petersen \& Rajan, 1997). On the other hand, suppliers bear adverse effects such as delinquency risk or buyer default risk while using trade credit. If a buyer defaults, then it jeopardizes suppliers' liquidity and may reduce profitability. Despite these risks, suppliers can set different prices depending on buyers' demand more freely than when they do not use trade credit. In addition, suppliers can acquire exclusive information in advance and use this advantage to play a key role between buyers and banks (Emery, 1984; Jain, 2001; Mian \& Smith, 1994). Consequently, current studies suggest that suppliers are also profitable (Hill, Kelly, \& Lockhart, 2012; MartinezSola, Garcia-Teruel, \& Martinez-Solano, 2014).

However, it is doubtful if the effect of trade credit is the same during both ordinary and contractionary periods. Some contributions demonstrate that using trade credit instead of bank loans is favorable in a monetary contraction (Atanasova, 2007; Mateut et al., 2006; McGuinness \& Hogan, 2016) and trade credit can play either a positive or negative signaling role for banks, depending on the economic conditions (Agostino $\&$ Trivieri, 2014; Love et al., 2007; Yang, 2011). The patterns of using trade credit vary between both periods; therefore, it is also likely that the determinants of trade credit are distinct during a crisis period and the effects on profitability are different. Several studies also show evidence that the role of trade credit declines gradually during economic recovery, i.e., there is no positive and significant relationship between trade credit and bank credit (Gertler \& Gilchrist, 1994; Love et al., 2007; Oliner \& Rudebusch, 1996). In other words, SMEs may perceive that trade credit is less profitable than bank credit, and could use bank credit instead of trade credit if their bank credit is available. Previous studies about the relationship between monetary contraction and trade credit are summarized in Table 1. Surprisingly, this implies that the effect of inevitable use of trade credit is uncertain, whereas careful use can be profitable. Consequently, we set up the hypotheses as follows:

H1: Trade payable (for buyer SMEs) is less profitable during the crisis than post-crisis period.

H2: Trade receivable (for supplier SMEs) is less profitable during the crisis than post-crisis period.

Using the same logic, we test the next hypotheses. If the condition of monetary contraction is a fundamental difference between the crisis and post-crisis periods, it is likely that trade credit of constrained SMEs is less profitable than that of unconstrained SMEs. For instance, even among SMEs, small-sized (constrained) firms find it more difficult to access bank credit than the large-sized (unconstrained) firms do. The criterion is referred to by Boissay and Gropp (2013) 
Table 1 : Summary of previous studies (1)

\begin{tabular}{|l|l|}
\hline \multicolumn{1}{|c|}{ Topic } & \multicolumn{1}{c|}{ Related papers } \\
\hline $\begin{array}{l}\text { Roles of trade credit } \\
\text { for buyer }\end{array}$ & $\begin{array}{l}\text { Brennan et al. (1988), Huyghebaert } \\
\text { (2006), Petersen and Rajan (1997), } \\
\text { Wilson and Summers (2002) }\end{array}$ \\
\hline $\begin{array}{l}\text { Profitability of trade } \\
\text { credit for supplier }\end{array}$ & $\begin{array}{l}\text { Hill et al. (2012), Martinez-Sola et } \\
\text { al. (2014) }\end{array}$ \\
\hline $\begin{array}{l}\text { Use of trade credit } \\
\text { in a monetary } \\
\text { contraction }\end{array}$ & $\begin{array}{l}\text { Agostino and Trivieri (2014), } \\
\text { Atanasova (2007), Love et al. } \\
\text { (2007), Mateut et al. (2006), } \\
\text { McGuinness and Hogan (2016), } \\
\text { Yang (2011) }\end{array}$ \\
\hline $\begin{array}{l}\text { Roles of trade credit } \\
\text { during economic } \\
\text { recovery }\end{array}$ & $\begin{array}{l}\text { Gertler and Gilchrist (1994), } \\
\text { Love et al. (2007), Oliner and } \\
\text { Rudebusch (1996) }\end{array}$ \\
\hline
\end{tabular}

and Martinez-Sola et al. (2014). Specifically, Martinez-Sola et al. (2014) show the positive relationship between firm size and liquidity and profitability of receivables, whereas this study analyzes the relationship in terms of both trade payable and receivable. Applying the same logic, trade credit of small-sized firms is less effective than that of large-sized firms. Therefore, the hypotheses are a comparison between constrained and unconstrained SMEs, as well as complement the aforementioned hypotheses ( $\mathrm{H} 1$ and $\mathrm{H} 2)$.

H3: Trade payable is more profitable for unconstrained firms than for constrained firms among SMEs.

H4: Trade receivable is more profitable for unconstrained firms than for constrained firms among SMEs.

\subsection{Firm Strategy and Profitability}

Buyers can decide their working capital policies with two options - aggressive (leveraging) and passive (deleveraging) policies. Trade credit has the function of price discrimination for buyers and also allows them to foster strong relationships with their suppliers over the long term $(\mathrm{Ng}$, Smith, \& Smith, 1999). Furthermore, trade credit is efficient for buyers because suppliers have cost advantages when credit is provided (Deloof, 2003; Petersen \& Rajan, 1997). Thus, the literature mentioned above supports the hypothesis that aggressive working capital policies increase buyers' profitability (Garcia-Teruel \& Martinez-Solano, 2007); it allows buyers to reduce production lead-time, and their accelerated business cycle improves profitability.

However, the effect can be adverse in the long term, post crisis. First, under general concepts, an excessively aggressive investment can be detrimental; more so when the financial conditions are not considered because firms are overly optimistic about their resilience. Specifically, it needs careful handling, as liquidity is a major concern for SMEs than larger firms. Secondly, SMEs' aggressive trade credit policy can become a warning signal for banks. While ordinary SMEs transfer from trade credit to bank credit, in contrast, the persistent use of trade credit seems a defective financial state. Thus, firms should try to find the optimal level of using trade credit to maximize their profitability (Deloof, 2003). The summary of previous studies is displayed in Table 2. Consequently, we assume that the strategy of mixed leveraging and deleveraging, depending on the financial state of SMEs, is the best approach in comparison with both the extreme cases - the continuously aggressive and passive strategies of trade credit.

H5: A mixed strategy of trade payable is superior in comparison with the continuously leveraging or deleveraging strategy of SMEs.

H6: A mixed strategy of trade receivable is superior in comparison with the continuously leveraging or deleveraging strategy of SMEs.

\section{Data and Variables}

\subsection{Dataset of Trade Credit}

The two benefits of using Korean trade credit data for testing our research question are completeness and uniqueness (we consider 6,627,995 transactions in Korea for the period 2008-2012). First, our Korean trade credit dataset includes transaction data of trade credit during the research period provided by Bank of Korea, the central bank of Korea. The Bank of Korea records all trade credit transactions of firms. Existing studies use theoretical models (Biais \& Gollier, 1997; Burkart \& Ellingsen, 2004; Meltzer, 1960; Schwartz, 1974; Wilner, 2000) or if they do conduct an empirical analysis, trade credit data are either survey data (Cheng \& Pike, 2003; Danielson \& Scott, 2004; Love \& Zaidi, 2010; McMillan \& Woodruff, 1999;

Table 2 : Summary of previous studies (2)

\begin{tabular}{|l|l|}
\hline \multicolumn{1}{|c|}{ Topic } & \multicolumn{1}{c|}{ Related papers } \\
\hline $\begin{array}{l}\text { Fostering strong } \\
\text { relationships between buyer } \\
\text { and supplier by using trade } \\
\text { credit }\end{array}$ & $\begin{array}{l}\text { Deloof (2003), Ng et al. } \\
\text { (1999), Petersen and Rajan } \\
(1997)\end{array}$ \\
\hline $\begin{array}{l}\text { The effect of aggressive } \\
\text { working capital policy } \\
\text { (ordinary period) }\end{array}$ & $\begin{array}{l}\text { Garcia-Teruel and Martinez- } \\
\text { Solano (2007) }\end{array}$ \\
\hline $\begin{array}{l}\text { Finding optimal strategy of } \\
\text { trade credit }\end{array}$ & Deloof (2003) \\
\hline
\end{tabular}


Ogawa, Sterken, \& Tokutsu, 2013) or indirect accounting data (Atanasova, 2007; Atanasova \& Wilson, 2004; de Blasio, 2005; Guariglia \& Mateut, 2006; Hill et al., 2012; Huang et al., 2011; Love et al., 2007; Martinez-Sola et al., 2014; Mateut et al., 2006; Nilsen, 2002; Niskanen \& Niskanen, 2006; Petersen \& Rajan, 1997) to show the role of trade credit, seemingly due to the lack of a complete transaction-based dataset. However, these methods have several limitations. First, actual validation of real-world occurrences is limited using the theoretical approach. Second, there are typical problems related to validity and reliability, such as concerns of accuracy and consistency in the survey data. Third, trade credit transactions that happen in the initial phase of the fiscal year are likely to be omitted as trade credit generally has a relatively short maturity. Therefore, Korean trade credit data can overcome these limitations and refine the results of the literature.

Second, Korean data has unique characteristics as compared to conventional trade credit data used in existing literature (Kwon, Yun, Han, Chung, \& Lee, 2018). Trade credit systems in Korea are peculiar in that commercial banks serve as an intermediary between the buyers and suppliers. Specifically, in Korea, in order to avoid bill discounting of credit for suppliers, banks provide liquidity to suppliers, immediately after the trade-credit transaction. Thus, suppliers can prevent a liquidity deficit - conventional trade credit does not provide this benefit. Korea's trade credit systems can be classified into two categories: accounts receivable financing (ARF) and supplier loan (SL). Both ARF and SL are types of trilateral bonds as they are intermediated by banks. The bank provides liquidity to the supplier firm immediately after the contract, and the buyer is required to repay the credit to the bank. A major difference between ARF and SL is whether indemnification of the unpaid credit is guaranteed. ARF has the properties of conventional trade credit. Compensation of unpaid credit is not guaranteed for a supplier using ARF. In other words, after an ARF-based contract is prepared between a supplier and a buyer, the supplier has to reimburse the bank instead of the buyer, in case the buyer cannot repay the credit amount. Under the SL system, however, the bank takes the responsibility for compensation and the supplier is not liable under any circumstances. In this respect, even if SL is not exactly a form of bank credit, it is closer to bank credit than ARF; thus, we only use ARF data for our research.

Thus, trade credit in Korea is concerned not only with the transacting firms, but also with commercial banks. The interests of three parties (buyers, suppliers, and banks) are intertwined in these transactions. Thus, banks should be vigilant about trade credit transactions between buyers and suppliers. Moreover, only a few unprofitable (or insolvent) firms can cause a liquidity shortage for both firms and banks. Therefore, trade credit risk is a sensitive issue for all financial institutions and their respective authorities, especially during a crisis period (see Rochet and Tirole (1996), Freixas, Parigi, and Rochet (2000), and Eisenberg and Noe (2001)). Consequently, Korean data is appropriate to test our research hypothesis, especially during a contractionary period, and thus it contributes to existing literature. Initially, we analyze the effects of the use of trade credit (ARF) on both buyers and suppliers in order to comprehend the effects of trade credit in Korea. We investigate the effects annually in order to identify those that are distinct to the crisis and post-crisis periods.

\subsection{Data Description}

We analyze all of the ARF transactions of Korean firms for the period 2008-2012. In order to investigate ARF completely, we use the summation of all individual transactions by each firm on an annual basis. All Korean firms that satisfy one of the following criteria release their financial and accounting statements to the public (Obtained from the Financial Services Commission in Korea): 1) firms with $>$ KRW 10 billion in total assets; 2) firms with $>$ KRW 7 billion in total assets and with $>$ KRW 7 billion in total debt; 3) those with $>$ KRW 7 billion in total assets and more than 300 employees; or 4) listed firms. Therefore, large companies are not included in the dataset. Specifically, our sample targets include all Korean SMEs that used ARF at least once during the given period and opened their financial information to the public.

The transaction datasets are obtained from the Bank of Korea. The data provide the coded identification number of a supplier, buyer, and the bank contracted, as well as the contract date, maturity date, and the balance in each transaction. Financial data of the firms are obtained from the KIS-Value from the National Information and Credit Evaluation (NICE) Information Service, which provides financial data of Korean firms. We exclude transactions that have broken values, such as those associated with irregular dates or negative values of the balance; abnormal values of the financial information are also excluded. We also rejected extreme values at $1 \%$ level to decrease the effect of outliers. Consequently, the sample analyzed in this study is an unbalanced panel with 16,845 observations for 5,751 firms during the period 2008-2012. Among those firms, 4,284 firms are manufacturing business and 578 firms belong to wholesale and retail industry. Specifically, among the manufacturing firms, 783 firms are related to machinery manufacturing and 521 firms belong to automotive industry. Table 3 shows the detailed statistics of those firms. 
Table 3 : Statistics of the firms

\begin{tabular}{|l|c|l|c|}
\hline \multicolumn{1}{|c|}{ Industry } & Obs & \multicolumn{1}{c|}{ Industry (Mfg.) } & Obs \\
\hline Manufacturing (C) & 4,284 & Primary metal (C24) & 343 \\
\hline Construction (F) & 423 & $\begin{array}{l}\text { Metal processing } \\
(\mathrm{C} 25)\end{array}$ & 368 \\
\hline Wholesale (G) & 578 & $\begin{array}{l}\text { Equipment in ICT } \\
(\text { C26) }\end{array}$ & 425 \\
\hline Others & 466 & Machinery (C29) & 783 \\
\hline & & Automobile (C30) & 521 \\
\hline & & Others & 1,844 \\
\hline
\end{tabular}

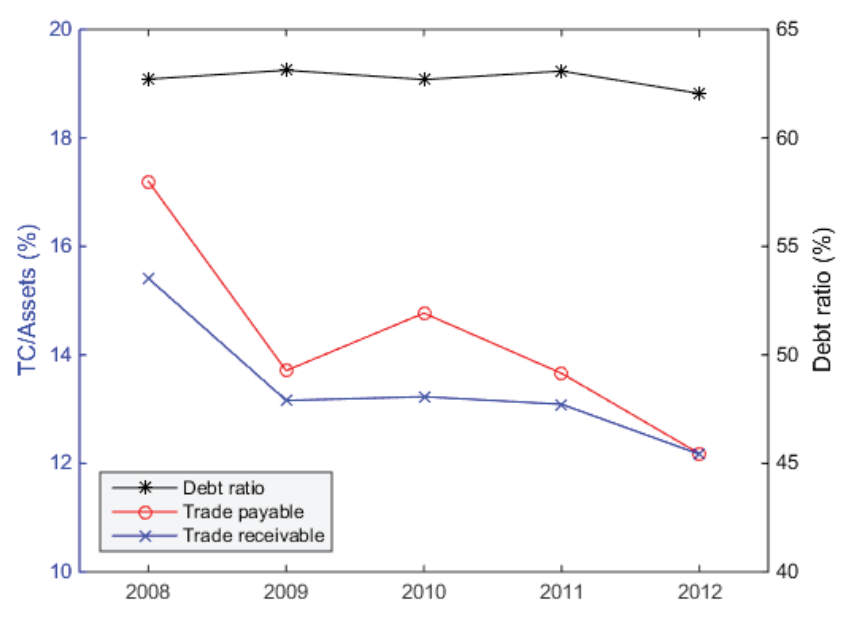

Figure 1 : Proportion of trade credit and debt ratio from 2008 to 2012 (Note A line with black and asterisk markers represents the debt ratio. Lines with red and circle markers, and with blue and cross markers denote trade payable and receivable, respectively. The left y-axis shows the values of trade credit, and the right $y$-axis indicates the debt ratio.)

Figure 1 shows the mean values of the ratio of the use of trade credit to total assets and the debt ratio of firms in the sample annually. As mentioned above, the use of trade credit depends on the economic conditions (Deloof \& La Rocca, 2015). While the average value of the debt ratio is invariant in $62-63 \%$, the ratio of trade credit fluctuates year-by-year. Trade payable occupies about $17.2 \%$ of the total assets on average in 2008, which is the maximum value during the period. Therefore, the proportion of trade payable has decreased during the period 2010-2012, and is the lowest in 2012. Similarly, the ratio of trade receivable tends to decline in 2008-2012. Finally, firms are inclined to extend their trade credit during a crisis period and use trade credit conservatively during a post-crisis period.

\subsection{Variables}

Error! Reference source not found. provides summary statistics of all the variables used in this study. The dependent variable is return on assets (ROA), which is a proxy of the profitability of firms (Garcia-Teruel \& Martinez-Solano, 2007; Lee, Kang, \& Kim, 2018; Martinez-Sola et al., 2014). ROA is calculated as the ratio of net income to total assets.

We are interested in the use of ARF. Each of these variables can be classified into payable and receivable. Thus, we use independent variables as follows - ARF payable (ARFpay) and ARF receivable (ARFrec) - each scaled by the total assets of firms. Even if the minimum values of ARF are presented as 0.000 in Error! Reference source not found., all of the values of the independent variables are nonzero. Moreover, we introduce year dummy variables to investigate annual effects of trade credit.

The control variables used in all the regressions are representative of firm size, leverage, growth opportunities, cash flow, and macroeconomic conditions (Hill et al., 2012; Kim \& Lee, 2017; Love et al., 2007; Martinez-Sola et al., 2014). Firm size is calculated as the logarithm of total assets (Size), and the debt ratio (DebtRatio), which is defined as the ratio of total liabilities to total assets, a proxy of leverage. Growth opportunities are measured as lagged annual growth of sales $\left(\right.$ Growth), i.e., $\left(\right.$ Sales $_{t}-$ Sales $\left._{t-1}\right) /$ Sales $_{t-1}$. Cash flow is the ratio of net cash flow to total assets $(C f w)$. Finally, we include GDP growth rate $(G D P)$ as a macroeconomic factor in all regressions (obtained from the Bank of Korea database). The sample is refined by eliminating $1 \%$ tail of both sides of the initial data.

Error! Reference source not found. reports the correlation matrix for all variables. The correlations between the dependent variable (ROA) and the independent variables are only negligible. In the case of the relationship between ROA and the control variables, significant correlations with DebtRatio (-0.364) and with $C f w(0.375)$ are observed. Finally, there are no significant correlations among independent and control variables indicative of multicollinearity.

\section{Empirical Model and Specification}

\subsection{Crisis Year}

As far as the financial crisis of 2008 is concerned, the Korean financial markets experienced spillover effects after large global financial institutions reported bankruptcy in September 2008 (See Duchin, Ozbas, and Sensoy (2010), Ivashina and Scharfstein (2010), and Hoshi and Kashyap (2010)). It is difficult to interpret the data of 2008 due to the coexistence of both the ordinary and crisis effects, even though trade credit is the most used credit source in 2008, according to Figure 1. We consider 2009 as the first year 
Table 4 : Summary statistics

\begin{tabular}{|c|c|c|c|c|c|c|c|}
\hline Variables & Obs & Firms & Mean & SD & Min & Median & Max \\
\hline \multicolumn{8}{|c|}{ Dependent variable } \\
\hline$R O A$ & 16,845 & 5,751 & 0.030 & 0.068 & -0.289 & 0.026 & 0.275 \\
\hline \multicolumn{8}{|c|}{ Independent variables } \\
\hline ARFpay & 5,889 & 1,872 & 0.141 & 0.142 & 0.000 & 0.096 & 0.722 \\
\hline ARFrec & 13,941 & 5,158 & 0.134 & 0.168 & 0.000 & 0.064 & 0.839 \\
\hline \multicolumn{8}{|c|}{ Control variables } \\
\hline Size & 16,845 & 5,751 & 10.383 & 0.284 & 9.910 & 10.330 & 11.712 \\
\hline DebtRatio & 16,845 & 5,751 & 0.627 & 0.184 & 0.090 & 0.659 & 0.971 \\
\hline Growth & 16,845 & 5,751 & 0.154 & 0.371 & -0.591 & 0.093 & 2.943 \\
\hline Cfw & 16,845 & 5,751 & 0.045 & 0.097 & -0.273 & 0.041 & 0.379 \\
\hline$G D P$ & 16,845 & 5,751 & 0.032 & 0.019 & 0.007 & 0.028 & 0.065 \\
\hline
\end{tabular}

Table 5 : Summary statistics

\begin{tabular}{|l|c|c|c|c|c|c|c|c|}
\hline & ROA & ARFpay & ARFrec & Size & DebtRatio & Growth & Cfw & GDP \\
\hline ROA & 1 & & & & & & \\
\hline ARFpay & $0.028^{*}$ & 1 & & & & & \\
\hline ARFrec & $0.036^{*}$ & $0.165^{*}$ & 1 & & & & \\
\hline Size & 0.000 & $-0.148^{*}$ & $-0.084^{*}$ & 1 & & & \\
\hline DebtRatio & $-0.364^{*}$ & $0.157^{*}$ & $0.098^{*}$ & $-0.191^{*}$ & 1 & & \\
\hline Growth & $0.209^{*}$ & $0.059^{*}$ & $0.070^{*}$ & 0.001 & $0.088^{*}$ & 1 & & \\
\hline Cfw & $0.375^{*}$ & 0.022 & $0.048^{*}$ & $-0.023^{*}$ & $-0.151^{*}$ & $0.130^{*}$ & 1 & \\
\hline GDP & $0.035^{*}$ & $0.030^{*}$ & 0.001 & $0.017^{*}$ & -0.001 & $0.184^{*}$ & $0.0186^{*}$ & 1 \\
\hline
\end{tabular}

Note: Asterisk (*) denotes significant at $5 \%$ level.

of the crisis, although bankruptcies were reported towards the end of 2008. Certainly, the crisis and post-crisis periods cannot be divided into distinct episodes. However, it is likely that the devastating effects of the crisis were greatest in 2009, and its influence declined gradually over time. We analyze the results as the effects of trade credit year-by-year during this period.

\subsection{Crisis and Post-Crisis Effects}

Our first model is designed for demonstrating the effects of the crisis and the unidentified influence during the post-crisis period. We perform the tests of the hypothesis twice, ARF payable and receivable. The test using Eq. (1) emphasizes individual aspects of firms as the buyers and suppliers. The result provides a microeconomic view of the profitability of trade credit systems for individual firms.
We generate year dummy variables, and then we make the independent variables with the interaction terms. Thus, the influence of the annual use of trade credit on profitability can be calculated. It is regressed twice as payable and receivable.

The first model is as follows:

$$
\begin{aligned}
& R_{i t}=\beta_{0}+\beta_{1} \times A_{R F p a y}\left(\text { or } \text { ARFrec }_{i t}\right) \times \\
& \text { Year }_{t}+\beta_{2} \times U_{i t}+\alpha_{i}+\text { Year }_{t}+\varepsilon_{i t}
\end{aligned}
$$

where ARFpay (or ARFrec) is the independent variable, $U$ is a vector of the control variables, is the firm individual effect, is the time dummy variables, and is the error term. The regression model of ARFpay shows the profitability of buyers, and the ARFrec model indicates that of the suppliers while using ARF. is a vector of the important coefficients since it represents the effect of trade credit annually using the interaction terms. According to the logic of Love et 
al. (2007), since ARFpay ${ }_{i t}\left(\right.$ or $\left.A R F r e c c_{i t}\right) \times$ Year $_{t}$ denotes the "separated" values in each year, it is represented as the simple effect, that is, the effect of the value of $A_{R F p a y}\left(\right.$ or $\left.A R F r e c_{i t}\right)$ in a single year. The expected result is that the effects on profitability are relatively significant in the post-crisis period, and the coefficients may be low or insignificant in the crisis period.

We use the fixed-effects (FE) model for estimation. If firm and time heterogeneities exist in our model, the FE estimator is more accurate than the ordinary least squares estimator is. We ran all of our models using the approach developed by White (1980) due to the presence of heteroscedasticity. Multicollinearity is not observed among the independent variables when we test using the variance inflation factor (VIF) and pairwise correlation matrix.

\subsection{Contraction and Strategy of SMEs}

The purpose of the second model is to analyze the difference of the effect between constrained and unconstrained SMEs. We set the classification criteria as firm size and liquidity (Boissay \& Gropp, 2013; MartinezSola et al., 2014). Size is the proxy of firm size and liquidity is measured as liquid assets and cash flow. After calculating the average values of the variables, firms within the sample are classified by whether their average values are median or more. Firms with greater values belonged to unconstrained firms; otherwise, they belonged to constrained firms. We tested the models of both hypotheses using Eq. (1).

For testing H5 and H6, we make a "leveraging score." If the proportion of trade credit of firm is increased or equal in comparison with last year, i.e., ARFpay ${ }_{i t} \geq A R F p a y_{i t-1}$ (certainly, the case of trade receivable is equally used), it is defined as "aggressive (leveraging) strategy" of trade credit and the score is "+1." If ARFpay ${ }_{i t}<A R F p a y_{i t-1}$, it is "passive (deleveraging) strategy" and the score is "-1." As the period of the dataset is five years, leveraging score can hold the value from +4 to -4 . Consequently, the aggressive strategy group is defined as firms that scored from +4 to +2 . Firms that scored from +1 to -1 belong to the mixed strategy group, and firms that recorded scores ranging from -2 to -4 belong to the passive strategy group. For example, if a firm extends trade credit from 2008 to 2010, cuts down from 2010 to 2011, and extends from 2011 to 2012 again, then the score is $+2-1+1=+2$. Also, the firm belongs to the aggressive strategy group. We test the models of the three groups individually with Eq. (1).

Similar to the first model, FE models with White estimator are used, and multicollinearity is not a concern in the models in Section 4.3.

\section{Results}

\subsection{Crisis Effects}

First, we analyze the crisis effects on SME profitability under ARF. For H1 and H2, Table 6 shows the results of the hypotheses of the effects on profitability using FE estimator in the crisis and post-crisis periods. We ran the test four times to assess the hypotheses as trade payable and receivable; first, the coefficients of the annual models are reported (model 1 and 3), next the model displays the regression result with the full control variables (model 2 and 4). The models (1)(2) and (3)-(4) show the crisis effects under ARFpay and ARFrec, respectively. In the model (1), the coefficients are seen increasing over time from 2009 to 2012, and the results are similar to those of the model (1) except the coefficient in 2009 in the model (2). In the case of trade receivable, the coefficients in the post-crisis period (2011-12) are greater than the crisis period (2009-10) (model 3), or those in the post-crisis period are only significant (model 4).

The results of $\mathrm{H} 1$ and $\mathrm{H} 2$ confirm that trade credit, both payable and receivable, becomes gradually profitable over time after the crisis period. Even though trade credit is used when bank credit is exhausted, it is possible that the use of trade credit is less profitable or ineffective in a contractionary period. Therefore, during a resilience period, extending trade credit is helpful for the profitability of SMEs. The results can be interpreted from both perspectives. First, SMEs require other approaches such as a retrenchment strategy or using other credits in a contractionary period since the effect of trade credit is insignificant or unsatisfactory. Second, the financial authority could implement other policies of financial support for rallying SMEs in a crisis period such as the deregulation of bank credit or the aid of other credits.

\subsection{Contraction of SMEs}

In this section, we show the results for $\mathrm{H} 3$ and $\mathrm{H} 4$ tests regarding the contraction of SMEs. Table 7 and 8 display the results of the hypotheses. Firms in the sample are classified by the median of the average value of total assets (size), liquid assets, and cash flow. Firms that are greater than the median belong to the "unconstrained" group and the other firms are included in the "constrained" group. In the case of trade payable (Table 7), unconstrained firms are more profitable compared to constrained firms in terms of size and cash flow during the post-crisis period. Conversely, the coefficient in 2012 of constrained firms is a little larger with regard to liquid assets and the others are insignificant. According to Table 8, the difference between unconstrained and constrained firms is ambiguous when using trade receivable. For example, in terms of size, the effect on profitability of constrained firms is a little larger in 2011. 
Table 6 : Multivariate analyses of the effect of accounts receivable financing (ARF) on profitability

\begin{tabular}{|c|c|c|c|c|}
\hline & \multicolumn{2}{|c|}{ Payable } & \multicolumn{2}{|c|}{ Receivable } \\
\hline & (1) & (2) & (3) & (4) \\
\hline \multirow[t]{2}{*}{ ARF * Year_2009 } & $0.032^{*}$ & 0.017 & 0.013 & 0.008 \\
\hline & $(1.76)$ & $(1.11)$ & $(1.48)$ & $(1.09)$ \\
\hline \multirow[t]{2}{*}{ ARF * Year_2010 } & $0.033^{* *}$ & $0.024^{*}$ & $0.016^{* *}$ & 0.000 \\
\hline & $(2.25)$ & (1.90) & $(2.24)$ & $(0.00)$ \\
\hline \multirow[t]{2}{*}{ ARF * Year_2011 } & $0.036^{\star *}$ & $0.027^{* *}$ & $0.034^{* * *}$ & $0.021^{* * *}$ \\
\hline & $(2.28)$ & (1.99) & $(4.20)$ & $(2.43)$ \\
\hline \multirow[t]{2}{*}{ ARF * Year_2012 } & $0.058^{* * *}$ & $0.038^{* *}$ & $0.024^{* *}$ & $0.020^{* *}$ \\
\hline & (3.37) & $(2.47)$ & $(2.47)$ & (2.43) \\
\hline \multirow[t]{2}{*}{ Size } & & $0.040^{* * *}$ & & $0.022^{* *}$ \\
\hline & & $(2.58)$ & & $(2.23)$ \\
\hline \multirow[t]{2}{*}{ DebtRatio } & & $-0.272^{* * *}$ & & $-0.295^{\star * *}$ \\
\hline & & $(-15.58)$ & & $(-26.44)$ \\
\hline \multirow[t]{2}{*}{ Growth } & & $0.043^{* * *}$ & & $0.038^{* * *}$ \\
\hline & & (15.89) & & (20.96) \\
\hline \multirow[t]{2}{*}{$C f w$} & & $0.110^{* * *}$ & & $0.099^{* * *}$ \\
\hline & & $(9.65)$ & & $(13.76)$ \\
\hline \multirow[t]{2}{*}{ GDP } & & $1.600^{*}$ & & -0.142 \\
\hline & & $(1.76)$ & & $(-0.26)$ \\
\hline \multirow[t]{2}{*}{ Const } & $0.029^{* * *}$ & -0.280 & $0.020^{* * *}$ & -0.021 \\
\hline & (13.38) & $(-1.63)$ & $(15.51)$ & $(-0.19)$ \\
\hline Firm fixed effects & Yes & Yes & Yes & Yes \\
\hline Year fixed effects & Yes & Yes & Yes & Yes \\
\hline Obs & 5,889 & 5,889 & 13,941 & 13,941 \\
\hline Firms & 1,871 & 1,871 & 5,158 & 5,158 \\
\hline$R^{\wedge} 2$ & .003 & .211 & .006 & .201 \\
\hline
\end{tabular}

Note: The coefficients are written in the first row, and their t-statistics are noted in the next row. Asterisks ${ }^{*},{ }^{* *}$, and ${ }^{* * *}$ denote significance at the $10 \%, 5 \%$, and $1 \%$ levels, respectively.

However, the effect on that of unconstrained firms is only significant, while the effect on that of constrained firms is insignificant. In addition, constrained firms are a little more profitable in respect of (liquid assets and cash flow).

Specifically, the hypothesis (H3) that trade payable is more advantageous for unconstrained firms is likely in most cases. The buyer firms, especially constrained buyers, should make a careful decision of trade payable. According to the results, constrained firms are rarely profitable when using trade payable. While the hypothesis is validated, it also supports other hypotheses ( $\mathrm{H} 1$ and $\mathrm{H} 2)$ that trade credit (specifically trade payable) is ineffective or less effective during a contractionary period. In contrast, the result for $\mathrm{H} 4$ test is unexpected, showing that although there is a crisis effect (or contraction) of trade credit on profitability of both buyers and suppliers, buyers are affected by the contraction more than suppliers are. It may be that other determinants are more important for supplier firms such as selecting buyer firms, rather than the economic conditions. 
Table 7 : Comparison of the effect between constrained and unconstrained SMEs on profitability (trade payable)

\begin{tabular}{|c|c|c|c|c|c|c|}
\hline & \multicolumn{2}{|c|}{ Size } & \multicolumn{2}{|c|}{ Liquid assets } & \multicolumn{2}{|c|}{ Cash flow } \\
\hline & Uncons. & Cons. & Uncons. & Cons. & Uncons. & Cons. \\
\hline ARFpay & -0.010 & $0.041^{* *}$ & 0.015 & 0.024 & 0.032 & -0.001 \\
\hline * Year_2009 & $(-0.38)$ & $(2.27)$ & $(0.71)$ & (1.02) & $(1.56)$ & $(-0.06)$ \\
\hline ARFpay & $0.035^{*}$ & 0.016 & 0.024 & 0.019 & $0.025^{*}$ & 0.020 \\
\hline * Year_2010 & (1.67) & (1.11) & $(1.52)$ & $(0.98)$ & (1.69) & $(0.99)$ \\
\hline ARFpay & $0.046^{* *}$ & 0.005 & 0.028 & 0.027 & 0.020 & 0.031 \\
\hline *Year_2011 & $(2.26)$ & $(0.29)$ & (1.61) & $(1.26)$ & (1.16) & $(1.49)$ \\
\hline ARFpay & $0.043^{*}$ & 0.032 & $0.036^{* *}$ & $0.055^{* *}$ & $0.046^{* *}$ & 0.025 \\
\hline * Year_2012 & $(1.85)$ & (1.59) & $(2.00)$ & (2.02) & $(2.10)$ & $(1.17)$ \\
\hline \multirow[t]{2}{*}{ Size } & 0.015 & $0.084^{\star * \star}$ & $0.065^{\star \star *}$ & 0.018 & $0.044^{*}$ & $0.039^{*}$ \\
\hline & $(0.71)$ & $(4.13)$ & $(3.10)$ & $(0.86)$ & (1.94) & $(1.89)$ \\
\hline \multirow[t]{2}{*}{ DebtRatio } & $-0.253^{\star * *}$ & $-0.298^{\star * *}$ & $-0.286^{* \star *}$ & $-0.262^{* * *}$ & $-0.238^{\star * *}$ & $-0.319^{* * *}$ \\
\hline & $(-10.49)$ & $(-12.31)$ & $(-11.70)$ & $(-10.69)$ & $(-10.23)$ & $(-11.46)$ \\
\hline \multirow[t]{2}{*}{ Growth } & $0.046^{* * *}$ & $0.038^{\star * *}$ & $0.044^{* * *}$ & $0.042^{* * *}$ & $0.042^{* * *}$ & $0.044^{* * *}$ \\
\hline & $(11.73)$ & $(10.28)$ & $(11.35)$ & $(10.92)$ & $(10.70)$ & $(11.48)$ \\
\hline \multirow[t]{2}{*}{$C f w$} & $0.103^{* * *}$ & $0.115^{\star \star *}$ & $0.106^{* * *}$ & $0.118^{* * *}$ & $0.124^{* * *}$ & $0.093^{* * *}$ \\
\hline & $(6.26)$ & $(7.30)$ & $(7.54)$ & $(6.29)$ & $(7.67)$ & $(5.72)$ \\
\hline \multirow[t]{2}{*}{ GDP } & 1.138 & $2.477^{\star *}$ & $3.527^{\star * *}$ & 0.252 & 1.936 & 0.770 \\
\hline & $(0.87)$ & $(2.05)$ & $(2.97)$ & $(0.19)$ & $(1.40)$ & $(0.63)$ \\
\hline \multirow[t]{2}{*}{ Const } & -0.031 & $-0.721^{\star \star *}$ & $-0.580^{\star *}$ & -0.034 & -0.354 & -0.224 \\
\hline & $(-0.13)$ & $(-3.26)$ & $(-2.49)$ & $(-0.14)$ & $(-1.37)$ & $(-0.98)$ \\
\hline Firm fixed effects & Yes & Yes & Yes & Yes & Yes & Yes \\
\hline Year fixed effects & Yes & Yes & Yes & Yes & Yes & Yes \\
\hline Obs & 3,081 & 2,808 & 2,980 & 2,909 & 2,995 & 2,894 \\
\hline Firms & 936 & 935 & 936 & 935 & 936 & 935 \\
\hline $\mathrm{R}^{\wedge} 2$ & .215 & .262 & .192 & .234 & .253 & .090 \\
\hline
\end{tabular}

Note: The coefficients are written in the first row, and their t-statistics are noted in the next row. Asterisks ${ }^{*},{ }^{* *}$, and ${ }^{* * *}$ denote significance at the $10 \%, 5 \%$, and $1 \%$ levels, respectively. Uncons. = Unconstrained, Cons. = Constrained. 
Table 8 : Comparison of the effect between constrained and unconstrained SMEs on profitability (trade receivable)

\begin{tabular}{|c|c|c|c|c|c|c|}
\hline & \multicolumn{2}{|c|}{ Size } & \multicolumn{2}{|c|}{ Liquid assets } & \multicolumn{2}{|c|}{ Cash flow } \\
\hline & Uncons. & Cons. & Uncons. & Cons. & Uncons. & Cons. \\
\hline ARFrec & 0.013 & 0.003 & 0.011 & 0.004 & $0.016^{* *}$ & -0.005 \\
\hline${ }^{*}$ Year_2009 & (1.33) & $(0.28)$ & $(1.06)$ & $(0.38)$ & $(2.08)$ & $(-0.37)$ \\
\hline ARFrec & 0.004 & -0.004 & 0.004 & -0.004 & 0.000 & 0.000 \\
\hline * Year_2010 & $(0.45)$ & $(-0.47)$ & $(0.46)$ & $(-0.42)$ & $(0.00)$ & $(0.01)$ \\
\hline ARFrec & $0.020^{* *}$ & $0.022^{* *}$ & $0.017^{*}$ & $0.025^{\star * *}$ & $0.020^{\star *}$ & $0.024^{\star *}$ \\
\hline${ }^{*}$ Year_2011 & $(2.29)$ & $(2.13)$ & $(1.72)$ & $(2.69)$ & $(2.35)$ & $(2.24)$ \\
\hline ARFrec & $0.026^{* *}$ & 0.015 & 0.016 & $0.025^{\star *}$ & $0.020^{*}$ & $0.022^{*}$ \\
\hline * Year_2012 & $(2.48)$ & $(1.22)$ & $(1.35)$ & $(2.22)$ & $(1.92)$ & $(1.71)$ \\
\hline \multirow[t]{2}{*}{ Size } & 0.017 & $0.030^{* *}$ & $0.050^{* * *}$ & -0.003 & $0.052^{* * *}$ & 0.001 \\
\hline & (1.29) & $(2.02)$ & (3.96) & $(-0.23)$ & $(3.80)$ & $(0.05)$ \\
\hline \multirow[t]{2}{*}{ DebtRatio } & $-0.273^{\star * *}$ & $-0.326^{\star * *}$ & $-0.318^{\star * *}$ & $-0.276^{* * *}$ & $-0.303^{* * *}$ & $-0.301^{* * *}$ \\
\hline & $(-18.70)$ & $(-18.78)$ & $(-20.40)$ & $(-17.16)$ & $(-18.74)$ & $(-18.79)$ \\
\hline \multirow[t]{2}{*}{ Growth } & $0.038^{* * *}$ & $0.037^{* * *}$ & $0.042^{* \star *}$ & $0.034^{* * *}$ & $0.039^{* * *}$ & $0.036^{* * *}$ \\
\hline & $(14.98)$ & $(14.69)$ & $(16.65)$ & $(13.25)$ & $(17.06)$ & $(13.26)$ \\
\hline \multirow[t]{2}{*}{$C f w$} & $0.095^{\star * *}$ & $0.104^{\star * *}$ & $0.084^{* * *}$ & $0.121^{* * *}$ & $0.115^{\star * *}$ & $0.081^{* * *}$ \\
\hline & $(9.44)$ & $(10.15)$ & $(8.89)$ & $(10.89)$ & $(11.80)$ & $(7.66)$ \\
\hline \multirow[t]{2}{*}{ GDP } & -0.118 & -0.022 & $1.493^{* *}$ & $-1.502^{*}$ & $1.829^{* *}$ & $-1.565^{* *}$ \\
\hline & $(-0.17)$ & $(-0.03)$ & $(2.10)$ & $(-1.88)$ & (2.39) & $(-2.04)$ \\
\hline \multirow[t]{2}{*}{ Const } & 0.011 & -0.075 & $-0.334^{* *}$ & 0.256 & $-0.372^{* *}$ & 0.233 \\
\hline & $(0.08)$ & $(-0.46)$ & $(-2.36)$ & $(1.55)$ & $(-2.44)$ & $(1.47)$ \\
\hline Firm fixed effects & Yes & Yes & Yes & Yes & Yes & Yes \\
\hline Year fixed effects & Yes & Yes & Yes & Yes & Yes & Yes \\
\hline Obs & 7,370 & 6,511 & 6,921 & 7,020 & 6,990 & 6,951 \\
\hline Firms & 2,581 & 2,577 & 2,579 & 2,579 & 2,579 & 2,579 \\
\hline$R^{\wedge} 2$ & .190 & .236 & .219 & .187 & .261 & .086 \\
\hline
\end{tabular}

Note: The coefficients are written in the first row, and their t-statistics are noted in the next row. Asterisks ${ }^{*},{ }^{* *}$, and ${ }^{* * *}$ denote significance at the $10 \%, 5 \%$, and $1 \%$ levels, respectively. Uncons. = Unconstrained, Cons. = Constrained.

\subsection{Leveraging Strategies of SMEs}

Table 9 shows the relationship between profitability and leveraging strategy of SMEs. To test H5 and H6, we set three strategies: aggressive, passive, and mixed strategy. We assume that if a firm tends to extend its trade credit during the resilience period continuously, the firm is included in the aggressive strategy group. Whereas, a firm that tends to reduce its trade credit belongs to the passive strategy group, and the mixed strategy group is in the borderline. The results show that instead of taking the extreme positions of aggressive and passive strategies, the approach that works best lies in the middle, although most strategies were insignificant in terms of both trade payable and receivable in 2009-10. 
Table 9 : Comparison of the effect among short-term investment strategies of SMEs on profitability

\begin{tabular}{|c|c|c|c|c|c|c|}
\hline & \multicolumn{3}{|c|}{ Payable } & \multicolumn{3}{|c|}{ Receivable } \\
\hline & Aggressive & Mixed & Passive & Aggressive & Mixed & Passive \\
\hline \multirow[t]{2}{*}{ ARF * Year_2009 } & 0.015 & 0.004 & $0.046^{*}$ & -0.016 & 0.004 & 0.016 \\
\hline & $(0.30)$ & $(0.17)$ & $(1.81)$ & $(-0.68)$ & $(0.49)$ & $(0.85)$ \\
\hline \multirow[t]{2}{*}{ ARF * Year_2010 } & -0.010 & 0.024 & 0.032 & -0.021 & -0.000 & -0.001 \\
\hline & $(-0.30)$ & $(1.40)$ & $(1.30)$ & $(-1.02)$ & $(-0.02)$ & $(-0.04)$ \\
\hline \multirow[t]{2}{*}{ ARF * Year_2011 } & -0.041 & $0.032^{*}$ & 0.041 & 0.001 & $0.024^{\star \star *}$ & 0.011 \\
\hline & $(-1.24)$ & (1.82) & $(1.48)$ & $(0.05)$ & $(2.84)$ & $(0.54)$ \\
\hline \multirow[t]{2}{*}{ ARF * Year_2012 } & -0.015 & $0.052^{* * *}$ & -0.016 & 0.003 & $0.023^{\star *}$ & -0.003 \\
\hline & $(-0.48)$ & $(2.59)$ & $(-0.43)$ & $(0.17)$ & $(2.20)$ & $(-0.13)$ \\
\hline \multirow[t]{2}{*}{ Size } & 0.018 & $0.040^{*}$ & $0.051^{\star *}$ & 0.030 & $0.029^{* *}$ & 0.002 \\
\hline & $(0.38)$ & $(1.91)$ & $(2.31)$ & $(0.96)$ & $(2.27)$ & $(0.14)$ \\
\hline \multirow[t]{2}{*}{ DebtRatio } & $-0.209^{* * *}$ & $-0.276^{* * *}$ & $-0.297^{* * *}$ & $-0.319^{* * *}$ & $-0.302^{* * *}$ & $-0.268^{* * *}$ \\
\hline & $(-3.98)$ & $(-12.69)$ & $(-9.35)$ & $(-8.19)$ & $(-21.79)$ & $(-12.71)$ \\
\hline \multirow[t]{2}{*}{ Growth } & $0.049^{* * *}$ & $0.043^{* * *}$ & $0.042^{* * *}$ & $0.040^{* * *}$ & $0.039^{* * *}$ & $0.035^{\star * *}$ \\
\hline & $(5.60)$ & $(12.56)$ & $(8.25)$ & $(7.54)$ & $(17.08)$ & $(9.59)$ \\
\hline \multirow[t]{2}{*}{ Cfw } & $0.129^{* * *}$ & $0.107^{* * *}$ & $0.103^{* * *}$ & $0.095^{\star * *}$ & $0.098^{* * *}$ & $0.102^{* * *}$ \\
\hline & $(3.84)$ & $(7.39)$ & $(5.19)$ & $(4.07)$ & $(11.16)$ & $(6.87)$ \\
\hline \multirow[t]{2}{*}{ GDP } & $-5.302^{* *}$ & $2.501^{* *}$ & 2.337 & -2.438 & 0.352 & -0.858 \\
\hline & $(-2.24)$ & $(2.02)$ & $(1.49)$ & $(-1.59)$ & $(0.49)$ & $(-0.88)$ \\
\hline \multirow[t]{2}{*}{ Const } & 0.081 & -0.302 & -0.398 & -0.034 & -0.101 & 0.185 \\
\hline & $(0.16)$ & $(-1.29)$ & $(-1.56)$ & $(-0.10)$ & $(-0.71)$ & $(0.94)$ \\
\hline Firm fixed effects & Yes & Yes & Yes & Yes & Yes & Yes \\
\hline Year fixed effects & Yes & Yes & Yes & Yes & Yes & Yes \\
\hline Obs & 728 & 3,696 & 1,465 & 1,461 & 9,621 & 2,859 \\
\hline Firms & 173 & 1,360 & 338 & 359 & 4,093 & 706 \\
\hline$R^{\wedge} 2$ & 239 & .202 & .235 & 190 & 188 & .254 \\
\hline
\end{tabular}

Note: The dependent variable is ROA in all of the models, and all variables are defined in Section 3.2. The coefficients are written in the first row, and their t-statistics are noted in the next row. Asterisks * ${ }^{* *}$, and ${ }^{* * *}$ denote significance at the $10 \%, 5 \%$, and $1 \%$ levels, respectively.

The investment strategy that is appropriate for each SME in terms of liquidity, can directly contribute to the profitability of buyers in a post-crisis period. We observe two merits of using a mixed policy for buyers. First, a buyer could gain market share steadily in and after a contractionary period, while competitors adopt an aggressive or passive liquidity policy. Second, transactions reinforce trust between buyers and suppliers so that suppliers become more profitable. According to Table 8, suppliers are less affected by a financial fluctuation than buyers are, relatively. Since suppliers are less sensitive to the economic conditions, there are other important aspects for suppliers such as controlling liquidity, selecting buyers, and liquidity strategies.

\section{Conclusion}

Management of trade credit is important under general economic conditions as it facilitates liquidity control for firms. Specifically, trade credit is required during a monetary contraction as an alternative to bank credit. Although 
previous studies suggest that trade credit is profitable, it is still uncertain how effective trade credit is during a severe contractionary period, such as the period immediately after a financial crisis. We use transaction-based complete and unique Korean trade credit data for investigating our research questions. More specifically, we investigate the profitability of ARF, which is a type of Korean trade credit, during the crisis and post-crisis periods in particular. We compare the effects of trade credit on firm profitability during and after the crisis period using data on ARF transactions, and financial and accounting statements of Korean firms for the period from 2009 to 2012.

Our results indicate that the use of trade credit during the crisis period is significantly less profitable than in the postcrisis period. Other results suggest that (1) the contraction tends to affect the profitability of buyer firms significantly, but not that of supplier firms when using trade credit and (2) the appropriate strategy for each firm is most profitable than using aggressive or passive strategy continuously. We show the results using the tests with annual models. The coefficients that represent the effect of trade credit tend to increase over time for both the buyers and suppliers. It appears that buyers can increase profitability by extending their market share, particularly during the resilience period. Since their policy of trade credit is an important factor that determines profitability, it seems to be the case that buyers are more susceptible to the crisis effect than suppliers are. In addition, our contribution is using the data for both buyers and suppliers to analyze contractionary and non-contractionary periods separately. Analyzing both firm types facilitates an extensive analysis than investigating from a one-sided position. Therefore, by analyzing each period separately, we observe that trade credit is a useful and important option, especially after a crisis or during a stable period.

Although our study contributes to the study of profitability of trade credit for both firm types, it has certain limitations. First, we cannot observe the effect in a pre-crisis period due to lack of data. Comparing the effect in the pre- and postcrisis periods will enable a thorough analysis of trade credit use. Second, we have only used data of Korean firms; other examples can show whether the crisis effect exists in firms in other countries. In addition, this study does not precisely investigate the sensitivity of the crisis for buyers or suppliers, such as the relationship of profitability between buyers and suppliers while using trade credit, which is an area for future research.

\section{References}

Agostino, M., \& Trivieri, F. (2014). Does trade credit play a signalling role? Some evidence from SMEs microdata. Small Business Economics, 42(1), 131-151.
Aloui, R., Ben Aissa, M. S., \& Nguyen, D. K. (2011). Global financial crisis, extreme interdependences, and contagion effects: The role of economic structure? Journal of Banking \& Finance, 35(1), 130-141.

Atanasova, C. (2007). Access to institutional finance and the use of trade credit. Financial Management, 36(1), 49-67.

Atanasova, C., \& Wilson, N. (2004). Disequilibrium in the UK corporate loan market. Journal of Banking \& Finance, 28(3), 595-614.

Biais, B., \& Gollier, C. (1997). Trade credit and credit rationing. Review of Financial Studies, 10(4), 903-937.

Boissay, F., \& Gropp, R. (2013). Payment defaults and interfirm liquidity provision. Review of Finance, 17(6), 1853-1894.

Brennan, M. J., Maksimovic, V., \& Zechner, J. (1988). Vendor financing. Journal of Finance, 43(5), 1127-1141.

Burkart, M., \& Ellingsen, T. (2004). In-kind finance: A theory of trade credit. American Economic Review, 94(3), 569-590.

Cheng, N. S., \& Pike, R. (2003). The trade credit decision: Evidence of UK firms. Managerial and Decision Economics, 24(6-7), 419-438.

Danielson, M. G., \& Scott, J. A. (2004). Bank loan availability and trade credit demand. Financial Review, 39(4), 579-600.

de Blasio, G. (2005). Does trade credit substitute bank credit? Evidence from firm-level data. Economic Notes, 34(1), 85-112.

Deloof, M. (2003). Does working capital management affect profitability of Belgian firms? Journal of Business Finance \& Accounting, 30(3-4), 573-588.

Deloof, M., \& La Rocca, M. (2015). Local financial development and the trade credit policy of Italian SMEs. Small Business Economics, 44(4), 905-924.

Duchin, R., Ozbas, O., \& Sensoy, B. A. (2010). Costly external finance, corporate investment, and the subprime mortgage credit crisis. Journal of Financial Economics, 97(3), 418-435.

Eisenberg, L., \& Noe, T. H. (2001). Systemic risk in financial systems. Management Science, 47(2), 236-249.

Emery, G. W. (1984). A pure financial explanation for trade credit. Journal of Financial and Quantitative Analysis, 19(3), 271285.

Freixas, X., Parigi, B. M., \& Rochet, J. C. (2000). Systemic risk, interbank relations, and liquidity provision by the central bank. Journal of Money, Credit, and Banking, 32(3), 611-638.

Garcia-Teruel, P. J., \& Martinez-Solano, P. (2007). Effects of working capital management on SME profitability. International Journal of Managerial Finance, 3(2), 164-177.

Gertler, M., \& Gilchrist, S. (1994). Monetary policy, business cycles, and the behavior of small manufacturing firms. Quarterly Journal of Economics, 109(2), 309-340.

Guariglia, A., \& Mateut, S. (2006). Credit channel, trade credit channel, and inventory investment: Evidence from a panel of UK firms. Journal of Banking \& Finance, 30(10), 2835-2856. 
Hill, M. D., Kelly, G. W., \& Lockhart, G. B. (2012). Shareholder returns from supplying trade credit. Financial Management, $41(1), 255-280$.

Hoshi, T., \& Kashyap, A. K. (2010). Will the US bank recapitalization succeed? Eight lessons from Japan. Journal of Financial Economics, 97(3), 398-417.

Huang, H., Shi, X. J., \& Zhang, S. M. (2011). Counter-cyclical substitution between trade credit and bank credit. Journal of Banking \& Finance, 35(8), 1859-1878.

Huyghebaert, N. (2006). On the determinants and dynamics of trade credit use: empirical evidence from business start-ups. Journal of Business Finance \& Accounting, 33(1-2), 305-328.

Ivashina, V., \& Scharfstein, D. (2010). Bank lending during the financial crisis of 2008. Journal of Financial Economics, 97(3), 319-338.

Jain, N. (2001). Monitoring costs and trade credit. The Quarterly Review of Economics and Finance, 41(1), 89-110.

Kim, S. S., \& Lee, J. H. (2017). Testing the liquidity hypothesis in the Korean retail firms. Journal of Distribution Science, 15(5), 29-38.

Kwon, O., Yun, S.-g., Han, S. H., Chung, Y. H., \& Lee, D. H. (2018). Network topology and systemically important firms in the interfirm credit network. Computational Economics, 51(4), 847-864.

Lee, J. H., Kang, Y. S., \& Kim, S. S. (2018). Corporate social responsibility and financial performance in Korean retail firms. Journal of Distribution Science, 16(5), 31-43.

Longstaff, F. A. (2010). The subprime credit crisis and contagion in financial markets. Journal of Financial Economics, 97(3), 436-450.

Love, I., Preve, L. A., \& Sarria-Allende, V. (2007). Trade credit and bank credit: Evidence from recent financial crises. Journal of Financial Economics, 83(2), 453-469.

Love, I., \& Zaidi, R. (2010). Trade credit, bank credit and financial crisis. International Review of Finance, 10(1), 125-147.

Martinez-Sola, C., Garcia-Teruel, P. J., \& Martinez-Solano, P. (2014). Trade credit and SME profitability. Small Business Economics, 42(3), 561-577.

Mateut, S., Bougheas, S., \& Mizen, P. (2006). Trade credit, bank lending and monetary policy transmission. European Economic Review, 50(3), 603-629.

McGuinness, G., \& Hogan, T. (2016). Bank credit and trade credit: Evidence from SMEs over the financial crisis. International Small Business Journal, 34(4), 412-445.

McMillan, J., \& Woodruff, C. (1999). Interfirm relationships and informal credit in Vietnam. Quarterly Journal of Economics, $114(4), 1285-1320$.
Meltzer, A. H. (1960). Mercantile credit, monetary policy, and size of firms. The Review of Economics and Statistics, 42(4), 429-437.

Mian, S. L., \& Smith, C. W. (1994). Extending trade credit and financing receivables. Journal of Applied Corporate Finance, 7(1), 75-84.

Ng, C. K., Smith, J. K., \& Smith, R. L. (1999). Evidence on the determinants of credit terms used in interfirm trade. Journal of Finance, 54(3), 1109-1129.

Nilsen, J. H. (2002). Trade credit and the bank lending channel. Journal of Money, Credit, and Banking, 34(1), 226-253.

Niskanen, J., \& Niskanen, M. (2006). The determinants of corporate trade credit policies in a bank-dominated financial environment: The case of Finnish small firms. European Financial Management, 12(1), 81-102.

Ogawa, K., Sterken, E., \& Tokutsu, I. (2013). The trade credit channel revisited: evidence from micro data of Japanese small firms. Small Business Economics, 40(1), 101-118.

Oliner, S. D., \& Rudebusch, G. D. (1996). Monetary policy and credit conditions: Evidence from the composition of external finance: Comment. American Economic Review, 86(1), 300-309.

Petersen, M. A., \& Rajan, R. G. (1997). Trade credit: Theories and evidence. Review of Financial Studies, 10(3), 661-691.

Rochet, J. C., \& Tirole, J. (1996). Interbank lending and systemic risk. Journal of Money, Credit, and Banking, 28(4), 733-762.

Samarakoon, L. P. (2011). Stock market interdependence, contagion, and the US financial crisis: The case of emerging and frontier markets. Journal of International Financial Markets Institutions \& Money, 21(5), 724-742.

Schwartz, R. A. (1974). An economic model of trade credit. Journal of Financial and Quantitative Analysis, 9(4), 643-657.

Sohn, K. W., \& Liu, W. (2015). The price of risk in the Korean stock distribution market after the global financial crisis. Journal of Distribution Science, 13(5), 71-82.

White, H. (1980). A heteroskedasticity-consistent covariance matrix estimator and a direct test for heteroskedasticity. Econometrica, 48(4), 817-838.

Wilner, B. S. (2000). The exploitation of relationships in financial distress: The case of trade credit. Journal of Finance, 55(1), 153-178.

Wilson, N., \& Summers, B. (2002). Trade credit terms offered by small firms: survey evidence and empirical analysis. Journal of Business Finance \& Accounting, 29(3-4), 317-351.

Yang, X. (2011). The role of trade credit in the recent subprime financial crisis. Journal of Economics and Business, 63(5), 517-529. 